\title{
The Use of Aviation Biofuels as an Airport Environmental Sustainability Measure: The Case of Oslo Gardermoen
}

\section{Airport}

\section{Glenn Baxter ${ }^{1 *}$, Panarat Srisaeng ${ }^{1}$, Graham Wild ${ }^{2}$}

\author{
${ }^{1}$ School of Tourism and Hospitality Management, Suan Dusit University, Hua Hin Prachaup Khiri Khan, Thailand \\ ${ }^{2}$ School of Engineering, RMIT University, Box 2476, Melbourne, Victoria, Australia 3000 \\ *Corresponding author: School of Tourism and Hospitality Management, Suan Dusit University, Hua Hin Prachaup Khiri \\ Khan, Thailand. Email g_glennbax@ dusit.ac.th
}

\begin{abstract}
In recent times, there has been a growing trend by airports and airlines to use aviation biofuel as an environment sustainability measure. Using an instrumental qualitative case study research design, this paper examines the evolution of sustainable aviation fuels at Oslo Airport Gardermoen. Oslo Airport Gardermoen was the first airport in the world to offer the first airport in the world to offer aviation biofuels to all airlines in 2016. The qualitative data were examined by document analysis. The study found that the use of sustainable aviation biofuels has delivered tangible environmental benefits to Oslo Gardermoen Airport. The usage of aviation biofuels has enabled the airport, and the airlines using sustainable aviation biofuels, to reduce their greenhouse gases by $10-15 \%$. Also, as part of Norway's efforts to reduce greenhouse gas emissions, the Norwegian Government have mandated that the aviation fuel industry must mix $0.5 \%$ advanced biofuel into jet fuel from 2020 onwards. Norway's Ministry of Climate and Environment's goal is that by $2030,30 \%$ of the airline fuel will be sustainable in nature and will have a positive climate effect. Avinor, the operator of Norway's airports, has a goal that by $2030,30 \%$ of aviation fuel supplied in Norway should be sustainable biofuel - this follows the Norwegian government's mandate.
\end{abstract}

Keywords

airlines, aviation bio-fuel, case study, Oslo Airport Gardermoen, sustainable operations

\section{Introduction}

Airports play a highly significant role in the global air transport value chain, acting as the interface point between the surface-based and air transport modes [1]. However, with growing environmental pressures being placed on airports and airlines alike, all areas of the air transport industry have 
increasingly moved towards making concerted attempts to reduce their respective carbon "footprints" [2]. Accordingly, airports all around the world are diligently working to make themselves more environmentally friendly [3, 4]. In addition, to the provision of airside and landside infrastructure, airports provide aircraft refuelling systems. The refuelling and defueling of aircraft is most frequently performed by connecting the aircraft refuelling system to an airport-based ground refuelling system, which is sometimes referred to as a "hydrant" system [5]. Airports, for example, Brisbane International Airport, Oslo Airport Gardermoen and Seattle-Tacoma International Airport, are increasingly focusing on the provision of bio-fuels as an environmental sustainability measure.

The global awareness to reduce greenhouse gas (GHG) emissions from the air transport industry, thereby making the overall air transport sector more environmentally friendly, has increased in recent times. In this context one principal driver has been the development of advanced biofuels for air transport [6]. Sustainable aviation fuel (SAF) refers to a blended end product consisting of conventional Jet A-1 and aviation biofuel which conforms to applicable to the ASTM Standard Specification D1655 or DEFSTAN 91-91 specifications for use in jet aircraft [7]. Sustainable jet fuels represent a very important element in the airline industry's strategy to reduce greenhouse gas emissions whilst at the same time satisfying the growing demand for air travel. Biofuels have already been used for some regular flights by various air airlines. As of June 2018, in excess of 130,000 commercial flights have been powered by biofuel [8]. For many years now, airlines have experimented with biofuels. The objective has been to reduce carbon emissions [9]. In addition, the replacement of fossil fuels by jet-biofuels is one of the primary strategies to attain the emission targets of decrease $\mathrm{CO} 2$ emissions by $50 \%$ by $2050[10,11]$.

Aircraft fuel is one of the largest operating costs encountered by airlines $[12,13]$, thus the airline industry is significantly impacted by world oil prices [14]. In addition, fossil fuel prices are increasingly becoming volatile, so it is therefore essential for the industry to introduce and industrialize alternative aviation fuels generated from renewable sources, particularly bio-mass [15].

Since 2007, Oslo Airport Gardermoen has placed a high focus on the use of aviation biofuels as a key environmental sustainability measure. Oslo Airport Gardermoen was the first airport in the world to offer aviation biofuels to all airlines serving the airport. The objective of this study is to examine Oslo Airport Gardermoen sustainable jet fuel strategies and identify the sources of aviation biofuels that are provided by the airport. Oslo Airport Gardermoen was also selected as the case company as data and background on the airport's aviation biofuels is readily available in the public domain.

The remainder of the paper is organized as follows. Section 2 presents a review of the aviation biofuels literature. The research methodology underpinning the study is presented in
Section 3. The case study is presented in Section 4. The key findings of the study are presented in Section 5.

\section{Background}

2.1 The Usage of Biofuels in the Aviation Industry

The aviation industry is predicted to become a significant market for advanced biofuels in the coming years. The increased use of biofuels can be contributed to:

- The air transport industry produces approximately $2 \%$ of the global CO2 emissions [16, 17];

- Airlines operational costs are substantially dependent upon fuel costs, which typically accounts for around $30 \%$ of the total costs $[16,18]$;

- Airlines will need to take concrete actions in view of their greenhouse gas emissions; and

- Sustainability will be a key factor to obtain public acceptance of any alternative fuels, hence, biofuels, that is, those biofuels produced with innovative greenhouse gas-efficient technologies from sustainably cultivated crops or agricultural residues/wastes, will represent the preferred option [16] (p. 768).

According to Gegg [19] (p. 34), "the requirement to develop commercially viable alternatives to traditional fossilbased liquid fuels for commercial aircraft is intensifying". One of the promising developments in the aviation fuel field is the development of liquid biofuels [19]. Unlike conventional jet fuel which is refined from crude oil [19], aviation biofuels are produced by chemically processing biomass (plant starches and sugars) to create a liquid energy source. While biofuels (especially ethanol and plant oils) have been utilized to power road transport vehicles since the 1970s, it is only within the past few years that new blends which are suitable for use in aircraft have been developed. Aviation biofuels that are presently undergoing flight testing with the major airlines throughout the world have been produced from a range of feedstocks and biomass including jatropha, coconuts, algae, domestic refuse, woodchips, and camelina (an edible green shrub) [19].

In excess of fifty airlines, including Air New Zealand, Alaska Airlines, KLM, Brazil-based GOL airlines, Qantas and Virgin Australia, have operated test flights using different types and blends of aviation biofuels. These fuels have been used on a range of different aircraft types in both revenue and non-revenue services. Most importantly, these aviation biofuels were regarded as good as conventional jet fuels as the test flights revealed no reported loss of engine performance [19].

To be acceptable for commercial use, aviation biofuel must:

- First be certified in accordance with the air transport industry's stringent safety and performance requirements; 
- The aviation biofuel must achieve a material reduction in lifecycle carbon emissions compared to traditional fossil-based jet fuel and meet comprehensive sustainability criteria, such as Roundtable on Sustainable Biomaterials (RSB) certification; and

- Be a 'drop-in' alternative to traditional fossil-based jet fuel to avoid costly redesign of engines, airframes or fuel delivery systems [20].

As noted earlier, relative to fossil fuels, sustainably produced aviation biofuels result in a reduction in greenhouse gas emissions across their life cycle (Figure 1). As can be observed in Figure 1, during each stage in the production and distribution chain, carbon dioxide is emitted through energy use for the extraction and transport functions. Carbon dioxide will be reabsorbed as the next generation of aviation biofuel feedstock is grown (Figure 1) [20].

Furthermore, whilst aviation biofuels are being promoted as a "green" alternative to the use of conventional jet fuel, several barriers to their widespread usage exist. Presently, the industry has been unable to produce enough biomass to replace conventional jet fuel. This has resulted in concerns that land will be used for biofuel crops rather than for food production which would thus impact the prices of world food prices. Other concerns include the high research and development costs of biofuel (and their relative cost versus jet fuel), uncertainties about the accounting procedures, the true-life cycle emissions savings and issues relating to fuel consistency [15] (p. 34).

\subsection{Alternative Fuels for the Air Transport Industry} Alternative aviation fuels can be produced from algae, camelina, halophytes, jatropha, and wastes, for example wastes of plant and animal origin as well as animal and municipal wastes [14]. The properties of alternative aviation biofuels are:

1. Reduced greenhouse gas emissions;

2. Renewable resources;

3. Compatibility with conventional jet fuels; and

4. Sustainability and clean burning [14] (p. 1237).

The types of alternative aviation biofuels include the following:

\subsubsection{Hydro-Processed Renewable Jet Fuels}

Hydro-processed renewable jet fuels (HRJs) are produced through the hydrodeoxygenation of vegetable oils, animal fats, waste grease, algal oil and bio oil. The major side products are water and propane [14, 21]. According to Gutiérrez-Antonio et al. [22] (p. 710), "the hydroprocessing pathway consists on the chemical conversion of triglyceride feedstock through hydrodeoxygenation, hydroisomerizing and hydrocracking to produce "biojet fuel". The hydro-processed renewable jet fuels are high energy biofuels that can be used as a fuel source without any blending [23]. One of the primary advantages of hydroprocessed renewable jet fuels is the reduction in the emissions of greenhouse gases, such as, carbon monoxide (CO), hydrocarbons (HC), nitrogen oxides (NOX), and particulate matter (PM) [14]. In addition, the hydroprocessed renewable jet fuels have a high cetane number and have high thermal endurance [23].

The hydro-processed renewable jet fuels (HRJs) can be used without the necessity to modify conventional aircraft engines. In addition, this fuel can be used as an additive or blended with conventional jet fuel. These fuels also avoid motor corrosion. Due to the good cold flow properties, these fuels are suitable for the operation of higher flights [23] (p.30). The lack of oxygen and sulphur in the fuel reduces its lubricity [14].

\subsubsection{Fischer Tropsch Fuels}

de Klerk [24] (p. 241) notes that "the Fischer Tropsch (F-T) synthesis is a conversion technology that was developed to convert any carbon-based material into an oil product that can be refined to conventional transportation fuels and petrochemical products". Fischer Tropsch fuels (F-T) are hydrocarbon fuels $[14,23]$. This fuel is produced through catalytic conversion of syn gas, which is a mixture of carbon monoxide (CO) and hydrogen (H2) [25, 26]. There are many types of biomass raw materials, for instance, woody crops, wood waste, grass crops, and agricultural residues, that can be used to produce syn gas [23]. The Fischer Tropsch fuels are normally clean burning, high value fuels, and are characterized by non-toxicity, zero emissions of nitrogen oxides, high cetane number, reduced particulate matter (PM), low Sulphur, and aromatic content. In addition, the combustion of the fuel is free of carbon dioxide and hydrocarbons [14] (p. 1233).

Unlike many other alternative fuels, Fischer Tropsch fuels do not require any special distribution infrastructure [14]. The Fischer Tropsch process is expensive [14, 27] and as a result of the less energy density, the Fischer Tropsch fuels offer low power and low fuel economy [14].

\subsubsection{Biodiesel}

Biodiesel is produced through the process of transesterification using animal fats or vegetable oils [23] (p.31). Biodiesel is a biodegradable fuel [28, 29] and has excellent lubricity $[14,23]$. Biodiesel offers several advantages when compared with other fuels, such as a high flash point and good miscibility with fossil derived fuels. Also, biodiesel offers lower greenhouse gas and sulphur emissions, and does not cause any water, soil, or air pollution due to its non-toxic properties [23].

However, biodiesel is not appropriate to use as an aviation fuel. The energy density of biodiesel is lower than the more conventional jet fuels [23] (p. 31). It also has low efficiency $[14,23]$. The cloud point of biodiesel is also higher than fossil fuel-based aviation fuel. This property results in negative impacts for high flights [23] (p. 31). Biodiesel contains saturated fatty acids [23, 30]. According to Unlu and Hilmioglu [23] 


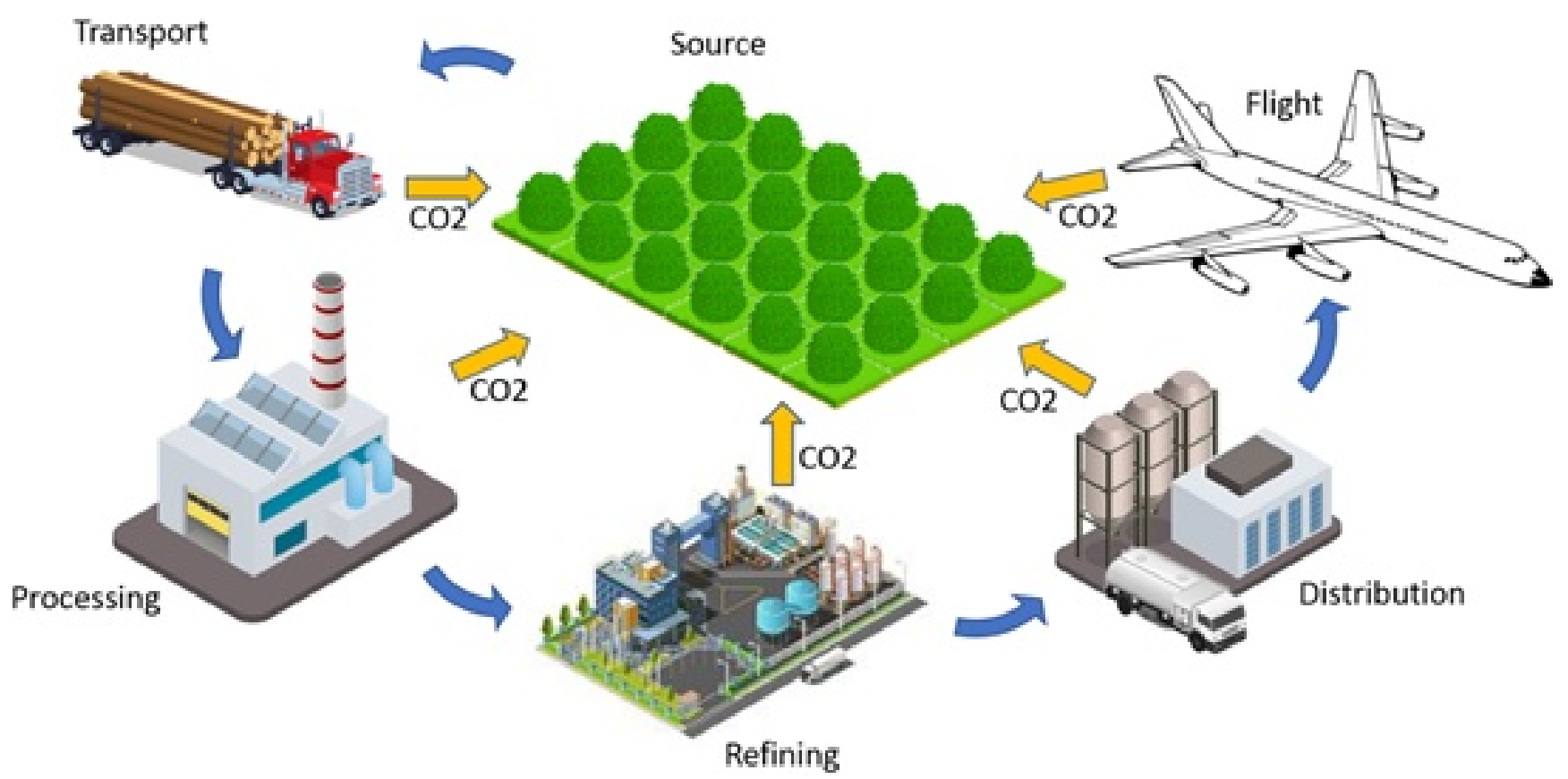

Figure 1. Aviation biofuel production process. Source: adapted from [21]. Each step in the process from transport to flight results in the production of $\mathrm{CO} 2$, which is then captured by the source as the cycle continues.

(p. 31), "these structures cause the decrement stability of the biodiesel". Accordingly, biodiesel is not presently attractive as an alternative aviation fuel $[14,23]$.

\subsubsection{Liquid Biohydrogen and Biomethane}

Liquid hydrogen is presently being established as an alternative jet fuel [23, 31, 32]. Biohydrogen is produced from an extensive diversity of biomass resources by following both thermal and biochemical methods [33]. Liquid hydrogen has a high energy density [34] but requires high storage volume [20, 35]. According to Kandaramath Hari et al. [20] (p. 1237), "the combustion of liquid hydrogen causes low emission of greenhouse gases compared to petroleum-based jet fuels".

The major issue with liquid hydrogen fuel is that it cannot be used as a fuel for conventional aircraft engines and, as a result, the engine(s) need to be modified [33]. Another problem associated with the use liquid hydrogen as a fuel source, is that upon mixing with air, it can burn in low concentration which will cause safety issues [14]. The storage of hydrogen in a liquid form is quite difficult since it requires a low temperature [36, 37, 38]. Also, the emission of comparatively high volumes of water vapor is a problem associated with hydrogen-powered aircraft [14] (p. 1237). However, liquid hydrogen fuels have low harmful emissions [34, 39].

Liquid methane can be used a fuel source in cryogenic aircraft $[14,23,40]$. Engine design is a difficulty that needs to be confronted for the commercialization of liquid methane fuels $[19,22]$. The combustion of liquid methane fuel results in the emission of methane [18], which is a powerful greenhouse gas [41].

\subsubsection{Bio Alcohols}

Ethanol and butanol are typically used as biofuels [23, 42]. However, bioethanol is not appropriate for the aviation industry due to its high volatility, low flash point, and energy density. The use of alcohol as a fuel source requires extra engine design and a special delivery infrastructure and storage system. The blending of alcohol with conventional aviation fuels is not feasible due to its poor fuel properties which will result in aviation-related issues [14, 23].

\section{Research Method}

\subsection{Research Method Used in the Study}

An instrumental case study research approach was used in this study $[43,44]$. An instrumental case study is the study of a case, for example, a firm, that provides insights into a specific issue, redraws generalizations, or builds theory $[45,46]$. The present study was designed around the established theory of sustainable aviation fuels $[18,23,47]$. The key issues examined in the present study were twofold. Firstly, the study examined Oslo Airport Gardermoen sustainable aviation biofuels initiatives, and secondly, the study examined the impact that sustainable fuels had on Oslo Airport Gardermoen infrastructure. Thus, as previously noted, Oslo Airport Gardermoen was the case firm examined in the study.

The research undertaken in the present study used a qualitative case study research design $[46,48]$. The goal of this approach is to expand and build theories rather than perform statistical analysis to test a study's specific hypothesis [49]. 


\subsection{Data Collection}

Data for the study was obtained from a range of documents, Oslo Airport Gardermoen company materials available on the internet, airline industry press articles, and media releases. These documents provided the sources of case evidence. The documents collected and examined in the study included Avinor A/S (owner and operator of Oslo Airport Gardermoen). annual sustainability reports, media releases, company presentations, and the airport's websites. An exhaustive search of the leading air transport magazines such as Airport World, Airline Business, Aviation Week and Space Technology and International Airport Review, was conducted. Applied Energy, Energy, Fuel Processing Technology, Renewable and Sustainable Energy Reviews, Journal of Air Transport Management and the Journal of Airport Management journals were also reviewed in the study. A search of the SCOPUS and Google Scholar databases was also undertaken.

The key words used in the database searches included "Oslo Airport Gardermoen sustainable fuel strategy", "sustainable aviation fuels", "Oslo Airport Gardermoen aviation biofuel regulatory framework", "flights powered by aviation biofuel", and "sources of sustainable aviation fuels at Oslo Airport Gardermoen".

Secondary data was therefore used in the study. The three principles of data collection as suggested by Yin [50] were followed: the use of multiple sources of case evidence, creation of a database on the subject and the establishment of a chain of evidence.

\subsection{Data Analysis Process}

The empirical data gathered for the study was examined using document analysis [51, 52]. Document analysis is quite frequently used in case studies and focuses on the information and data from formal documents and company records that were gathered in the study $[53,54,55]$. The documents collected for the present study were examined by four key criteria: authenticity, credibility, representativeness and meaning $[56,57]$.

The documents collected in the study were all readily available in the public domain. In the present study, the evidence for the case study was corroborated using various kinds of documents that were sourced from various sources, for example, company media releases, articles publishing in the leading air transport and airport industry magazines, and relevant articles published on the Internet [58]. No major difficulties were experienced in obtaining the documents as all the relevant documents could be easily accessed in the public domain. The evidence found in the documents collected and used for the present study were all clear and comprehensible [59].

The document analysis process in the study was undertaken in six distinct phases which followed the recommendations of O'Leary [60]:

- Phase 1: This phase involved planning the types and required documentation and their availability;
- Phase 2: The data collection involved gathering the documents and developing and implementing a scheme for the document management;

- Phase 3: Documents were reviewed to assess their authenticity, credibility and to identify any potential bias;

- Phase 4: The content of the collected documents was interrogated, and the key themes and issues were identified;

- Phase 5: This phase involved the reflection and refinement to identify and difficulties associated with the documents, reviewing sources, as well as exploring the documents content; and

- Phase 6: The analysis of the data was completed in this final phase of the study [60] (p. 179).

Following the guidance of Yin [50], all the collected documents were downloaded and stored in a case study database. The documents collected for the study were all in English. Each document was carefully read, and key themes were coded and recorded. This also study followed the recommendation of van Schoor [59] (p. 94), who has noted that in order to avoid bias, documents from different sources should also be carefully analyzed in the study. In addition, triangulation was utilized to add discipline to the study. This was achieved by collecting documents from multiple sources. This approach helped verify the themes that were detected in the documents gathered in the study [61, 62].

\section{Results}

\subsection{A Brief Overview of Oslo Airport Gardermoen}

Oslo opened a new airport at Gardermoen, a redundant military airfield, in 1998 replacing the bustling, compact Oslo Fornebu Airport. The new airport related high-speed train and improved road system to the airport cost almost NOK 20 billion (\$USD 3 billion) [63]. Oslo Airport Gardermoen (OSL) is Norway's major airport and air traffic hub. The airport is operated by Oslo Lufthavn AS, which was incorporated in 1992. Oslo Lufthavn AS is a subsidiary of Avinor AS [64].

The airport is in the municipality of Ullensaker, approximately 47 kilometres north of Oslo [65]. Oslo Airport Gardermoen occupies an area of 13 square kilometres and has two runways 2,950 and 3,600 metres in length, respectively. The airport has a total of 72 gates ( 44 with aerobridges) and 7 gates (4 Code D and 3 Code F) located at the cargo terminals [66].

The two largest airlines serving the airport are SAS Scandinavian Airlines and Norwegian Air Shuttle. Direct flights are operated to 31 domestic, 116 international and 18 intercontinental destinations. A new passenger terminal, which opened in April 2017, has expanded the airport's s annual capacity to 32 million passengers [67].

Figure 2 presents the annual enplaned passengers (domestic and international passenger) at the airport from 2007 to 
2017. The global financial crisis had an adverse impact on passenger travel with the annual number of enplaned passengers at Oslo Airport Gardermoen declining from 2008 to 2009. Since 2010, both domestic and international passenger traffic has shown a steady increase (Figure 2). A comparable situation occurred in 2009 following the global financial crisis of late 2008. Figure 2 also shows that international passengers comprise the largest share on enplaned passengers at Oslo Airport Gardermoen.

Figure 3 presents the total annual domestic and international aircraft movements at Oslo Airport Gardermoen from 2007 to 2017. As can be observed in Figure 3, both domestic and international aircraft movements declined in 2009 following the downturn in passenger demand, largely due to the global finanical crisis (GFC). Since 2010, there has been a steady increase in the number of domestic and international aircraft movements at Oslo Airport Gardermoean. Also, as can be observed in Figure 3, international aircraft movements comprise the largest share of aircraft movements at he airport.

\subsection{Oslo Airport Gardermoen Sustainable Aviation Fuel Regulatory Framework}

On 18 August 2018, the consultation process by Norway's Ministry of Climate and Environment on a proposal to introduce a mandate requiring all commercial jet fuel sold in the country to contain $1 \%$ of sustainable aviation fuel (SAF) from 1 January 2019 closed. The objective of the consultation was to bring the mandate into line with road transport requirements for fuel suppliers, with the sustainable aviation fuels (SAF) percentage expected to increase to $30 \%$ by 2030 . The Norwegian Government consultation, sought input on market conditions and estimates on possible volumes of aviation biofuels that may be available from 2019, received responses from a variety of key stakeholders including SAS Oil Norway, Neste Oil, Widerøe and Aviation Fueling Services Norway, as well as SkyNRG. The State-owned airport operator Avinor was also involved with the Norwegian government and civil aviation authority in investigating the feasibility of the mandate [69].

In October 2018, The Ministry of Climate and Environment announced that airlines operating in Norway must use more environmentally friendly jet fuel mixed with biofuel from 2020. As part of Norway's efforts to reduce greenhouse gas emissions, the Norwegian Government have mandated that the aviation fuel industry must mix $0.5 \%$ advanced biofuel into jet fuel from 2020 onwards. The Ministry of Climate and Environment's goal is that by $2030,30 \%$ of the airline fuel will be sustainable with a good climate effect. This new mandate corresponds to around 6 million litres of what is also known as second-generation biofuels, a product of waste and leftovers. The aviation biofuels used in Norway cannot be based on palm oil [70]. In June 2017, Norway became the first country in the world to ban the procurement of palm oilbased biofuels by state-run bodies, such as Avinor - Norway's airport operator [71].
The announcement released by the government indicates that the mandate will be flexible in that it will be up to obligated parties to determine when and where they blend the required biofuel. Norway's Environmental Protection Agency predicts the mandate will reduce greenhouse gas (GHG) emissions by 14,000 metric tons during the first year of operation [72].

Despite there being other initiatives and aviation biofuel trials around the world, Norway's move to legislate biofuels use in aviation may be the first legislation introduced worldwide on the topic [70].

In addition, Norway is one of 72 countries that have signed up to the United Nation's International Civil Aviation Organization's voluntary programme of carbon-neutral air travel growth, which will commence in 2020 [72].

\subsection{Oslo Airport Gardermoen Sustainable Aviation Fuel Industry Body Memberships}

The partners of the Nordic Initiative for Sustainable Aviation (NISA) have created a regional body with the objective of facilitating and strengthening the conditions for commercial and continuous access to sustainable jet fuels. As part of its aims, the initiative will identify the goals that may be achieved over different timeframes as well as the sustainability aspects for different pathways in light of national legislations, EU Sustainability Criteria and international sustainability guidelines [73].

An essential goal of the organization is to also coordinate with initiatives and activities set up by industry organizations such as the International Air Transport Association (IATA) and the Air Transport Action Group ATAG, United National bodies like the International Civil Aviation Organization (ICAO), EU initiatives as Flight Path 2020 as well as other relevant initiatives [73].

They Nordic Initiative for Sustainable Aviation will focus on bringing together key stakeholders throughout the supply chain - agriculture, technology suppliers, investors, regulators, producers and oil suppliers - to determine the best and most energy efficient solutions, whilst at the same time working with policy-makers in response to the aviation sector's sustainable fuel requirements [74].

The Nordic Initiative for Sustainable Aviation (NISA) is comprised of airports, airlines and their industry federations, and aviation authorities. Airport operators who are part of NISA include Avinor as well as Copenhagen Airports, Swedavia, Finavia and Isavia [75]. Norwegian Air Shuttle and Scandinavian Airlines (SAS) are members of this key industry body [73].

\subsection{Sustainable Aviation Fuel at Oslo Airport Gar- dermoen}

In 2007, the Norwegian air transport industry commenced an examination of sustainable jet biofuel. Sustainable aviation biofuel was certified for use in civil aviation operation in 2009 [76]. On 19 November 2014, SkyNRG Nordic, the partnership between SkyNRG and Statoil Fuel \& Retail Aviation, 


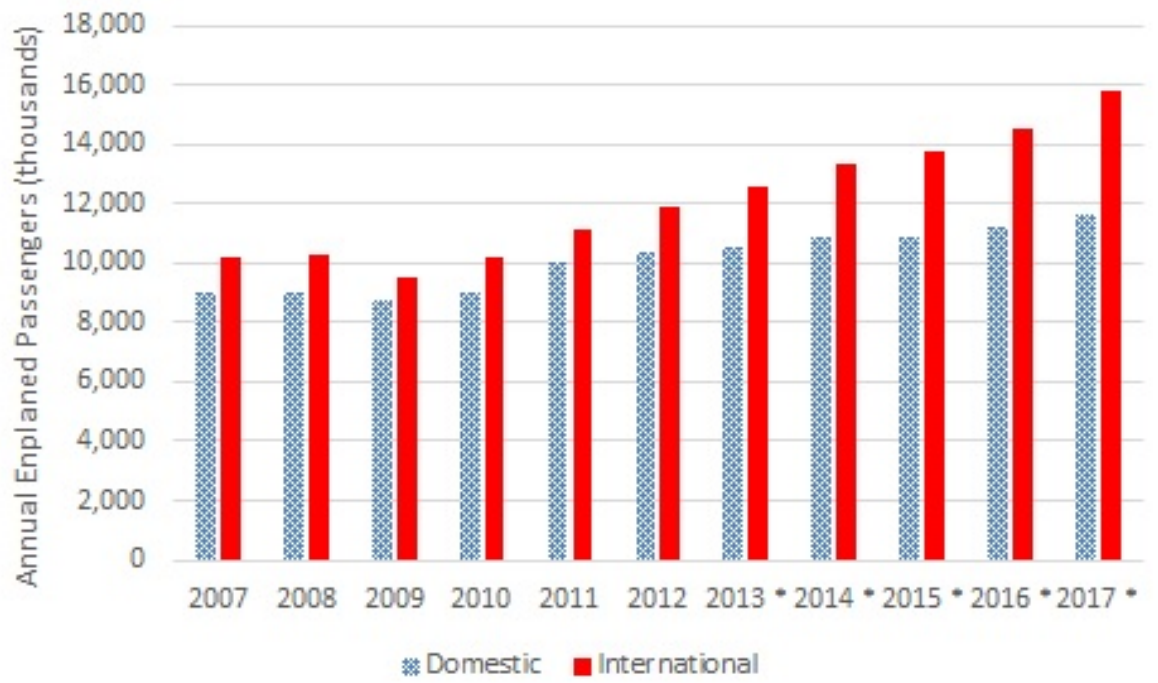

Figure 2. Total annual enplaned passengers (domestic/international) at Oslo Airport Gardermoen:2007-2017. Source: data derived from [68].

announced the supply of the first commercial quantities of sustainable bio jet fuel to Avinor's Oslo Airport Gardermoen in 2015. The Norwegian airports operator Avinor played a crucial role in the commercial scale purchasing agreements by offering a unique airport incentive for biofuel powered flights, which is open to all airlines. Lufthansa was the first airline to sign up, followed by Scandinavian Airlines System (SAS) and KLM Royal Dutch Airlines [77].

On March 31, 2016, KLM Royal Dutch Airlines commenced the first in a series of 80 flights from Oslo to Amsterdam using a sustainable biofuel blend to power an Embraer E190 jet aircraft. The flights were planned to operate over a period of five to six weeks and wood use around 200 tonnes of blended biofuel in a mix of 47 percent neat biofuel and 53 percent fossil fuel [78].

Oslo Airport Gardermoen was the first airport in the world, just ahead of Los Angeles International Airport, to start offering jet biofuel to its airline customers [78]. The first flights utilizing jet biofuel in Norway were conducted by Scandinavian Airlines (SAS) and Norwegian Air Shuttle in November 2014 [79]. In January 2016, Oslo airport in collaboration with AirBP, Neste, SkyNRG, Lufthansa Group, KLM, and SAS - became the first international airport in the world to supply biofuel for all airlines refuelling there. According to Avinor A.S, a total of 1.25 million litres of sustainable jet biofuel were used in Norway in 2016. This corresponded to 0.1 per cent of all jet fuel sold in the country [80] (p. 36). The sustainable aviation biofuel was delivered to the airport's main fuel farm and was distributed through the hydrant and dispenser system [76]. The European Union emissions trading system (ETS) and Norway's carbon dioxide (CO2)-tax was waived [76]. In the fourth quarter of 2016, a new supply of biofuel was received from AltAir, a company that is based in California. It was the first time in the history that biofuel has been distributed at an airport together with fossil fuels from the central tanking facility. This practice has reduced costs significantly [78].

The first batch of aviation biofuel (600,000 litres) was based on camelina and came from the "Initiative Towards Sustainable Kerosene for Aviation" (ITAKA) project in Spain. The fuel was refined by Neste in Finland and subsequently shipped to Gävle in, Sweden where it was blended with fossil JetA1 (50/50). The aviation biofuel was transported to Oslo Airport Gardermoen by road transport, and upon arrival at the airport it was dropped into the airport's fuel farm and was subsequently distributed in the airport's fuel dispenser system [76].

The second batch of aviation biofuel (650,000 litres) was based on used cooking oil. The cooking oil was refined by AltAir, who are in California, US. This was the first-time jet biofuel was imported to Europe. Similar to the first batch, the batch was shipped to Shipped to Gävle in Sweden, and was subsequently transported to Oslo Airport Gardermoen by road transport [76].

The supply of aviation biofuel in Norway was expanded in August 2017 to include Bergen airport, Flesland. There was very limited availability of jet biofuel in the market in 2017. As a result, the mixture of only 125,000 litres of jet biofuel was available for use during 2017 [80].

In addition, Avinor has allocated up to NOK 100 million for a ten-year period (2013-2022) for measures and projects contributing to the introduction of jet biofuel in Norwegian aviation. Together with the airlines and the Federation of Norwegian Aviation Industries (NHOLuftfart), Avinor has investigated the potential for establishing the large-scale production of biofuels for aviation using biomass from the Norwegian forestry industry. The studies have revealed that this can be realized between 2020 and 2025. Avinor has also worked with 


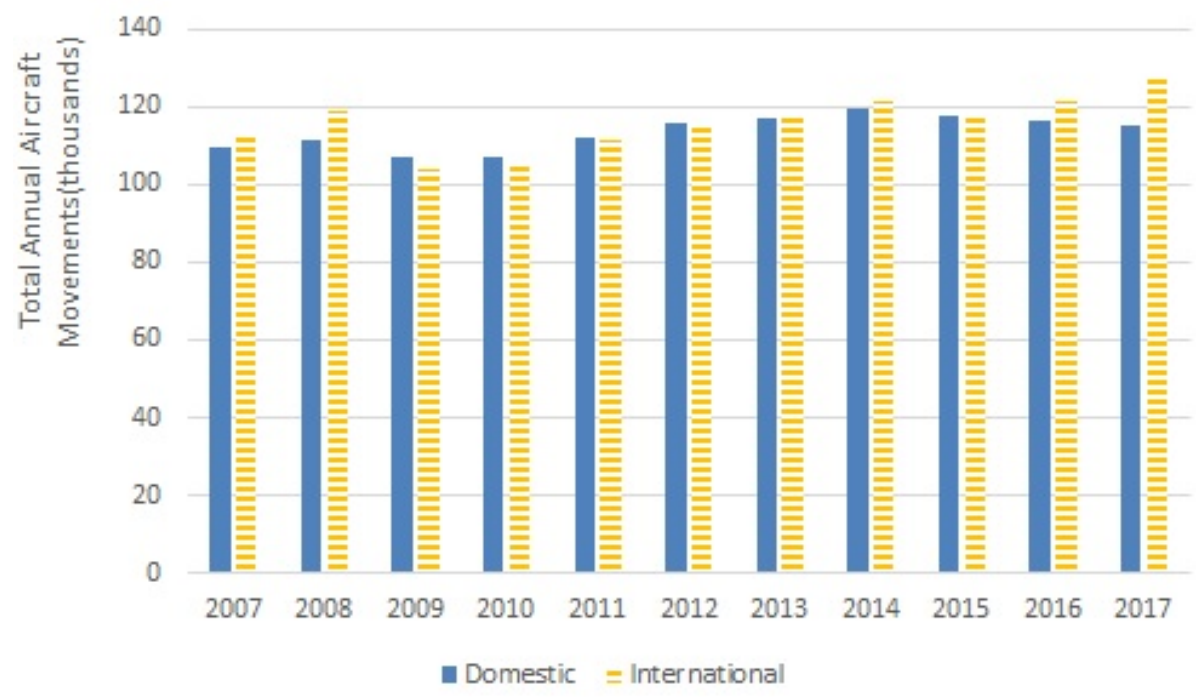

Figure 3. Total annual aircraft movements (domestic/international) at Oslo Airport Gardermoen:2007-2017. Source: data derived from [68].

a number of stakeholders on the production of jet biofuel for aviation in Norway. In addition, Avinor supports several research projects related to this, including in collaboration with SINTEF, BI Norwegian Business School, and the Norwegian University of Life Sciences [80] (p. 36).

Avinor has a goal that by $2030,30 \%$ of aviation fuel supplied in Norway should be sustainable biofuel. This would equate to around 400 mililitres [76].

Of the various forms of biomass that are suitable for the production of sustainable jet biofuel in Norway, the greatest potential from a ten-year perspective lies in forestry. The resource potential of the sea (algae) is also quite significant. However, this type of resource is not anticipated to be available in large volumes by 2030. Thus, forest-based source materials are therefore anticipated to be the most suitable resource until 2030. For the biofuel produced from forestry, it is important to note that the aviation industry in Norway will only use those parts of the tree which cannot be used for products, for example, construction materials [81].

Jet biofuel can also potentially be imported from overseas [79] (p. 36). In terms of importing alternative fuels, common source materials for biofuel production include waste products, for example, cooking oil and slaughterhouse waste, and also vegetable oils from plants such as camelina and jatropha. There are also specific plans and projects in countries including the United States of America to produce sustainable aviation biofuel from both household waste and recycled plastic [81] (pp. 18-19).

As previously noted, the biofuels sold to airlines in Norway are produced without palm oil or palm oil products [78].

\subsection{The Environmental Benefits of Sustainable Avi- ation Fuel for Oslo Airport Gardermoen}

Avinor has noted that a single bio-fuel plant can produce enough bio-jet fuel and bio-diesel to reduce greenhouse gas emissions from Norwegian aviation by $10-15 \%$, whilst at the same time yield major emission cuts in road transport. Thus, aviation bio-fuel production offers environmental benefits for Norway through reduced greenhouse gas emissions as well as the increased value creation from forests. The use of sustainable aviation biofuels is an important step towards a sustainable industry in Norway and a shift towards the country's renewable zero discharge society [82].

\section{Conclusion}

This study has examined the evolution of the use of sustainable aviation biofuels at Oslo Airport Gardermoen. Oslo Airport Gardermoen was the first airport in the world to offer aviation biofuels to all airlines serving the airport. The use of sustainable aviation biofuels has attracted a lot of attention in the literature and this study adds additional insights into the use of aviation biofuels as an airport sustainable environmental measure. This study utilized a qualitative case study research design. The documents gathered as case evidence were examined using a document analysis approach. The qualitative case study was underpinned by the case study research framework that followed the guidance of Yin [51].

The study found that the use of sustainable aviation biofuels has delivered tangible environmental benefits. The usage of aviation biofuels has enabled the airport, and the airlines using sustainable aviation biofuels, to reduce their greenhouse gases by $10-15 \%$. Also, as noted in the case study, as part of Norway's efforts to reduce greenhouse gas emissions, the Norwegian Government have mandated that the aviation fuel industry must mix $0.5 \%$ advanced biofuel into jet fuel from 2020 onwards. The Ministry of Climate and Environment's goal is that by $2030,30 \%$ of the airline fuel will be sustainable with a good climate effect. This new mandate corresponds to around 6 million litres of sustainable aviation biofuel per 
annum. Avinor, the operator of Norway's airports, has a goal that by $2030,30 \%$ of aviation fuel supplied in Norway should be sustainable biofuel - this follows the Norwegian government's mandate.

The study also found that the first batch of aviation biofuel was based on camelina. The production of sustainable aviation biofuels from farm and forestry waste, and from used cooking oil, results in a reduction in emissions when compared with the performance of fossil fuels. It is from these more environmentally friendly sources that Oslo Airport Gardermoen takes its biofuels.

\section{References}

[1] Glenn Baxter, Panarat Srisaeng, and Graham Wild. An assessment of airport sustainability, part 1-waste management at copenhagen airport. Resources, 7(1):21, 2018. doi: 10.3390/resources7010021. URL https : //doi.org/10.3390/resources7010021.

[2] Tom Allett. Alternative power. Airports International, (12), Sep 2011. URL http: //www.airportsinternational.com/2011/ $09 / a l t e r n a t i v e-p o w e r / 6380$.

[3] Nurhan Oto, Nesrin Cobanoglu, and Cevat Geray. Education for sustainable airports. Procedia - Social and Behavioral Sciences, 47:1164-1173, 2012. doi: 10.1016/j.sbspro.2012.06.795. URL https://doi. org/10.1016/j.sbspro.2012.06.795.

[4] Signe Vanker, Mart Enneveer, and Margit Mäsak. IMPLEMENTATION OF ENVIRONMENTALLY FRIENDLY MEASURES AT TALLINN AIRPORT. Aviation, 17 (1):14-21, March 2013. doi: 10.3846/16487788. 2013.774938. URL https://doi .org/10.3846/ 16487788.2013 .774938 .

[5] Roy Langton. Aircraft fuel systems. Wiley, Chichester, West Sussex, U.K. Hoboken, NJ, 2008. ISBN 978-0470057087.

[6] Ulf Neuling and Martin Kaltschmitt. Techno-economic and environmental analysis of aviation biofuels. Fuel Processing Technology, 171:54-69, March 2018. doi: 10.1016/j.fuproc.2017.09.022. URL https://doi. org/10.1016/j.fuproc.2017.09.022.

[7] Nicholas S. Bardell and Michael J. Ashton. Some issues affecting potential stakeholder uptake of sustainable aviation fuel within australia: a case study conducted at darwin international airport. Australian Journal of Mechanical Engineering, pages 1-13, 2018.

[8] Justin Bachman. Airlines' biofuel-powered flights might soon take off. Bloomberg.com. URL https://www.bloomberg.com/news / articles/2018-09-13/airlines-biofuelpowered-flights-might-soon-take-off.
[9] Denise Zanatta Martini, Luiz Eduardo Oliveira e Cruz de Aragão, Ieda DelArco Sanches, Marcelo Valadares Galdos, Cinthia Rubio Urbano da Silva, and Eloi Lennon Dalla-Nora. Land availability for sugarcane derived jet-biofuels in são paulo-brazil. Land Use Policy, 70:256-262, January 2018. doi: 10.1016/j.landusepol. 2017.10.035. URL https://doi.org/10.1016/ j.landusepol.2017.10.035.

[10] Ausilio Bauen and Lucy Nattrass. Sustainable aviation biofuels: scenarios for deployment. In Martin Kaltschmitt and Ulf Neuling, editors, Biokerosene: Status and prospects, chapter 27, pages 703-721. SpringerVerlag, Berlin, 2018.

[11] Tracey Dodd, Marc Orlitzky, and Tim Nelson. What stalls a renewable energy industry? industry outlook of the aviation biofuels industry in australia, germany, and the USA. Energy Policy, 123:92-103, December 2018. doi: 10.1016/j.enpol.2018.08.048. URL https : //doi.org/10.1016/j.enpol.2018.08.048.

[12] Bijan Vasigh. Engineering Economics for Aviation and Aerospace. Routledge, December 2016. doi: 10.4324/9781315644257. URL https : / / doi .org/ $10.4324 / 9781315644257$.

[13] Bijan Vasigh. Foundations of airline finance : methodology and practice. Routledge, Taylor \& Francis Group, New York, 2015. ISBN 9780415743259.

[14] Eldad Yosef. The evolution of the US airline industry : theory, strategy and policy. Springer, Dordrecht, 2005. ISBN 0387242139.

[15] Thushara Kandaramath Hari, Zahira Yaakob, and Narayanan N. Binitha. Aviation biofuel from renewable resources: Routes, opportunities and challenges. Renewable and Sustainable Energy Reviews, 42:12341244, February 2015. doi: 10.1016/j.rser.2014.10. 095. URL https://doi.org/10.1016/j.rser. 2014.10 .095 .

[16] David Chiaramonti, Matteo Prussi, Marco Buffi, and Daniela Tacconi. Sustainable bio kerosene: Process routes and industrial demonstration activities in aviation biofuels. Applied Energy, 136:767774, December 2014. doi: 10.1016/j.apenergy.2014. 08.065. URL https://doi.org/10.1016/j. apenergy.2014.08.065.

[17] Holly A. Edwards, Darron Dixon-Hardy, and Zia Wadud. Aircraft cost index and the future of carbon emissions from air travel. Applied Energy, 164: 553-562, February 2016. doi: 10.1016/j.apenergy. 2015.11.058. URL https://doi.org/10.1016/ j.apenergy.2015.11.058. 
[18] Luís A. B. Cortez, Francisco E. B. Nigro, Luiz A. H. Nogueira, André M. Nassar, Heitor Cantarella, Márcia A. F. D. Moraes, Rodrigo L. V. Leal, Telma T. Franco, Ulf F. Schuchardt, and Ricardo Baldassin Junior. Perspectives for sustainable aviation biofuels in brazil. International Journal of Aerospace Engineering, 2015:1-12, 2015. doi: 10.1155/2015/264898. URL https : / / doi . org/10. $1155 / 2015 / 264898$.

[19] Per Gegg, Lucy Budd, and Stephen Ison. The market development of aviation biofuel: Drivers and constraints. Journal of Air Transport Management, 39: 34-40, July 2014. doi: 10.1016/j.jairtraman.2014. 03.003. URL https://doi.org/10.1016/j. jairtraman.2014.03.003.

[20] Emily Nelson. Green aviation : reduction of environmental impact through aircraft technology and alternative fuels. CRC Press/Balkema, The Netherlands Boca Raton, 2017. ISBN 9780415620987.

[21] Creating a sustainable future with aviation biofuels. Qantas US. URL https://www.qantas.com/ travel/airlines/sustainable-aviationfuel/global/en.

[22] Rickard Arvidsson, Sara Persson, Morgan Fröling, and Magdalena Svanström. Life cycle assessment of hydrotreated vegetable oil from rape, oil palm and jatropha. Journal of Cleaner Production, 19(2-3):129137, January 2011. doi: 10.1016/j.jclepro.2010.02.008. URL https://doi.org/10.1016/j.jclepro. 2010.02 .008 .

[23] C. Gutiérrez-Antonio, F.I. Gómez-Castro, J.A. de LiraFlores, and S. Hernández. A review on the production processes of renewable jet fuel. Renewable and Sustainable Energy Reviews, 79:709-729, November 2017. doi: 10.1016/j.rser.2017.05.108. URL https: //doi.org/10.1016/j.rser.2017.05.108.

[24] Derya Unlu and Nilufer Durmaz Hilmioglu. Review of renewable fuels in the aviation sector. In Tahir Karakoc, editor, Advances in Sustainable Aviation, chapter 3, pages 25-39. Springer International Publishing, Cham, 2017. ISBN 978-3-319-67133-8.

[25] A. de Klerk. Aviation turbine fuels through the fischertropsch process. In Christopher Chuck, editor, Biofuels for aviation : feedstocks, technology and implementation, chapter 10, pages 241-259. Academic Press, Amsterdam, 2016. ISBN 9780128045688.

[26] Yatish Shah. Chemical energy from natural and synthetic gas. CRC Press, Boca Raton, Florida, 2017. ISBN 9781498738026.

[27] Adorjan Kurucz. Syngas : production methods, post treatment and economics. Nova Science Publishers, New York, 2009. ISBN 9781607418412.
[28] John Graham Mathew J. De Wit, Edward Corporan and Donald Minus. Effects of aromatic type and concentration in fischer-tropsch fuel on emissions production and material compatibility. Energy Fuels, 22:2411-2418, 2008.

[29] Ayhan Demirbas. Algae energy : algae as a new source of biodiesel. Springer, London, 2010. ISBN 978-1-84996049-6.

[30] Ram Gupta. Gasoline, diesel, and ethanol biofuels from grasses and plants. Cambridge University Press, New York, 2010. ISBN 978-0521763998.

[31] A. H. Scragg. Biofuels, production, application and development. CABI, Wallingford, Oxfordshire, UK Cambridge, MA, 2009. ISBN 978-1845935924.

[32] Bhupendra Khandelwal, Adam Karakurt, Paulas R. Sekaran, Vishal Sethi, and Riti Singh. Hydrogen powered aircraft : The future of air transport. Progress in Aerospace Sciences, 60:45-59, July 2013. doi: 10.1016/j. paerosci.2012.12.002. URL https://doi .org/10. $1016 / j \cdot$ paerosci.2012.12.002.

[33] Milan Janić. An assessment of the potential of alternative fuels for "greening" commercial air transportation. Journal of Air Transport Management, 69:235-247, June 2018. doi: 10.1016/j.jairtraman. 2017.09.002. URL https://doi.org/10.1016/ j.jairtraman.2017.09.002.

[34] Mustafa Balat and Mehmet Balat. Political, economic and environmental impacts of biomass-based hydrogen. International Journal of Hydrogen Energy, 34 (9):3589-3603, May 2009. doi: 10.1016/j.ijhydene. 2009.02.067. URL https://doi.org/10.1016/ j.ijhydene.2009.02.067.

[35] S.J. Canfer and D. Evans. Properties of materials for use in liquid hydrogen containment vessels. In $\mathrm{U}$ Balachandran, editor, Advances in cryogenic engineering materials, pages 253-260. Springer Science+Business Media, New York, 1998. ISBN 978147579058-0.

[36] Michael B. Charles, Paul Barnes, Neal Ryan, and Julia Clayton. Airport futures: Towards a critique of the aerotropolis model. Futures, 39(9):1009-1028, November 2007. doi: 10.1016/j.futures.2007.03.017. URL https://doi.org/10.1016/j.futures. 2007.03 .017 .

[37] Kathy. Materials in energy conversion, harvesting, and storage. Wiley, Hoboken, New Jersey, 2014. ISBN 9781-118-88910-7.

[38] Robert Evans. Fueling our future : an introduction to sustainable energy. Cambridge University Press, Cambridge New York, 2007. ISBN 978-0521684484. 
[39] A. Midilli, M. Ay, I. Dincer, and M.A. Rosen. On hydrogen and hydrogen energy strategies. Renewable and Sustainable Energy Reviews, 9(3):255-271, June 2005. doi: 10.1016/j.rser.2004.05.003. URL https: //doi.org/10.1016/j.rser.2004.05.003.

[40] C. Koroneos, A. Dompros, G. Roumbas, and N. Moussiopoulos. Advantages of the use of hydrogen fuel as compared to kerosene. Resources, Conservation and Recycling, 44(2):99-113, May 2005. doi: 10.1016/j.resconrec. 2004.09.004. URL https://doi.org/10.1016/ j.resconrec.2004.09.004.

[41] Saeed Farokhi. Aircraft propulsion. John Wiley \& Sons, Hoboken, NJ, 2009. ISBN 9780470039069.

[42] Robert W. Howarth, Renee Santoro, and Anthony Ingraffea. Methane and the greenhouse-gas footprint of natural gas from shale formations. Climatic Change, 106(4): 679-690, April 2011. doi: 10.1007/s10584-011-00615. URL https://doi.org/10.1007/s10584011-0061-5.

[43] John Love. Biofuels and bioenergy. John Wiley \& Sons, Inc, Chichester, West Sussex, 2017. ISBN 9781118350560.

[44] Gina Grandy. Instrumental case study. In Albert Mills, editor, Encyclopedia of case study research, volume 1, pages 473-475. Sage Publications, Thousand Oaks, Calif, 2009. ISBN 978-1412956703.

[45] Robert Stake. The art of case study research. Sage Publications, Thousand Oaks, 1995. ISBN 978-0803957671.

[46] Robert E. Stake. Qualitative case studies, 2005.

[47] Hans Doorewaard. Conceptional model: Causal model study. In Albert Mills, editor, Encyclopedia of case study research, volume 1, pages 202-203. Sage Publications, Thousand Oaks, Calif, 2009. ISBN 978-1412956703.

[48] Walter Palmer. Will sustainability fly? : aviation fuel options in a low-carbon world. Ashgate Publishing Company, Surrey, England, 2015. ISBN 9781409430919.

[49] Alan Bryman. Social research methods. Oxford University Press, Oxford New York, 2012. ISBN 9780199588053.

[50] Abd Rahman Abdul Rahim and Mohd Shariff Nabi Baksh. Case study method for new product development in engineer-to-order organizations. Work Study, 52(1):25-36, February 2003. doi: 10.1108/ 00438020310458705. URL https://doi .org/10. $1108 / 00438020310458705$.

[51] Robert Yin. Case study research and applications : design and methods. SAGE Publications, Inc, Thousand Oaks, California, 2018. ISBN 978-1506336169.
[52] Glenn Baxter and Panarat Srisaeng. Cooperating to compete in the global air cargo industry: The case of the DHL express and lufthansa cargo a.g. joint venture airline 'AeroLogic'. Infrastructures, 3(1):7, March 2018. doi: 10.3390/infrastructures3010007. URL https : / / doi . org/10.3390/infrastructures3010007.

[53] Glenn Baxter and Panarat Srisaeng. The strategic deployment of the airbus a350-900xwb aircraft in a fullservice network carrier route network: The case of singapore airlines. Infrastructures, 3(3):25, July 2018. doi: 10.3390/infrastructures3030025. URL https : / / doi . org/10.3390/infrastructures3030025.

[54] J Garcia. Enacting electronic government success : an integrative study of government-wide websites. Springer, Place of publication not identified, 2014. ISBN 978-14939-0021-3.

[55] Helen Simons. Case study research in practice. SAGE, Los Angeles London, 2009. ISBN 978-0761964247.

[56] Briony Oates. Researching Information Systems and Computing. SAGE Publications Ltd, London, 2005. ISBN 9781446235447.

[57] John Scott. A matter of record: documentary sources in social research. Polity Press B. Blackwell, Cambridge, UK Cambridge, MA, USA, 1990. ISBN 0745600301.

[58] Tanya Fitzgerald. Documents and documentary analysis. In Ann Briggs, editor, Research methods in educational leadership management, chapter 20, pages 296-308. SAGE, London, 2012. ISBN 9781446200438.

[59] Kristin Shrader-Frechette and Earl D. McCoy. Community ecology, population biology, and the method of case studies. In David Keller, editor, The philosophy of ecology : from science to synthesis, chapter 12, pages 153169. University of Georgia Press, Athens, 2000. ISBN 9780820322209.

[60] Berta Schoor. Fighting corruption collectively : how successful are sector-specific coordinated governance initiatives in curbing corruption. Springer VS, Wiesbaden, 2017. ISBN 9783658178376.

[61] Zina Leary. The essential guide to doing research. SAGE, London Thoundand Oaks, 2004. ISBN 0761941991.

[62] Pamela L. Morris. Triangulation. In Mike Allen, editor, The SAGE encyclopedia of communication research methods, pages 1781-1783. SAGE Reference, Los Angeles, CA, 2017. ISBN 9781483381435.

[63] Glenn Baxter. Capturing and delivering value in the transatlantic air travel market: The case of the air france-KLM, delta air lines, and virgin atlantic airways strategic joint venture. MAD - Magazine of Aviation Development, 7(1): 
17-37, January 2019. doi: 10.14311/mad.2019.01.03. URL https://doi.org/10.14311/mad.2019. 01.03 .

[64] Joan Feldman. 25 years to life. Air Transp. World, 9(35): 91-96, 1998.

[65] Company overview of oslo lufthavn as. Bloomberg.com, URL https://www.bloomberg.com/ research/stocks/private/snapshot.asp? privcapId=22674431.

[66] Oslo airport - europe's most efficient airport. International Airport Review, . URL https: //www. internationalairportreview.com/ article/3989/oslo-airport-europesmost-efficient-airport/.

[67] About oslo airport - avinor. avinorno, . URL https://avinor.no/en/corporate/ airport/oslo/about-us/about-osloairport/tall-og-fakta.

[68] Oslo airport facts - avinor. avinorno, . URL https://avinor.no/en/aviation/market/ oslo-airport-facts/.

[69] Traffic statistics - avinor. avinor.no, . URL https://avinor.no/en/corporate/ airport/oslo/about-us/traffic_ statistics/trafikkstatistikk.

[70] Norwegian government closes consultation on a 1biofuels. Norwegian government closes consultation on a 1proposal for aviation biofuels on GreenAir Online, - URL https://www.greenaironline.com/ news $\cdot$ php? viewstory $=2513$.

[71] Lefteris Karagiannopoulos. Norway will make airlines use more environmentally friendly fuel from 2020. Reuters, Oct 2018. URL https: / / www .reuters.com/article/us-norwaybiofuels/norway-will-make-airlinesuse-more-environmentally-friendlyfuel-from-2020-idUSKCN1ME25U.

[72] John McKenna. Norway's airports pump planes with biofuels. World Economic Forum. URL https: / / www . weforum.org/agenda/2017/ 11/norway-airports-biofuels-avinor/.

[73] Erin Voegele. Norway to implement biofuel mandate for aviation fuel in 2020 @biomassmagazine. Biomassmagazine.com. URL http: / / biomassmagazine.com/articles / 15657 / norway-to-implement-biofuelmandate-for-aviation-fuel-in-2020.
[74] International Civil Aviation Organization. Nordic initiative for sustainable aviation (nisa). Initiatives Projects. URL https://wWw.icao.int/ environmental-protection/GFAAF/Pages/ Project. aspx?Project ID $=25$.

[75] Green Air. Nordic aviation sector joins with boeing and airbus to launch a regional sustainable biofuels initiative. URL https://www.greenaironline. com/news . php?viewstory $=1780$.

[76] Olav Mosvold Larsen. Experience from introduction of aviation biofuel at oslo airport. URL https: / / www . nordicenergy . org/wpcontent/uploads/2016/09/Expereincefrom-introduction-of-aviationbiofuel-at-oslo-airport-Olav-MosvoldLarsen.pdf.

[77] Oslo to become biohub powered by skynrg nordic and avinor. Aviation, . URL https: //aviationbenefits.org/newswire/2014/ 11/oslo-to-become-biohub-powered-byskynrg-nordic-and-avinor/.

[78] Klm trials biofuel-powered flights between amsterdam and oslo. Reuters, Mar 2016. URL https: //www.reuters.com/article/airlinesbiofuels-klm/klm-trials-biofuelpowered-flights-between-amsterdamand-oslo-idUSL5N1734WP.

[79] Annual and csr report 2016. . URL https: //avinor.no/globalassets/_konsern/omoss/rapporter/en/avinor-annualreport-2016.pdf.

[80] Annual and csr report 2017. . URL https: //avinor.no/globalassets/_konsern/omoss/rapporter/en/avinor-annualreport-2017.pdf.

[81] Avinor and norwegian aviation 2017. . URL https://avinor.no/globalassets / _konsern/om-oss/rapporter/en/avinorrapport_uk_v1.pdf.

[82] First hub in the world with regular bio-fuel deliveries. International Airport Review, . URL https: / / www.internationalairportreview.com/ news/18124/first-hub-world-regularbio-fuel-deliveries/. 